\title{
Analysis of Casting Defect, Tensile Strength, and Hardness of Al-Si Casting Alloy with Percentage Variation of Clay Binder Bangkalan
}

\author{
Imam Muhtarom ${ }^{1,3}$, and Sunomo ${ }^{1}$ \\ ${ }^{1}$ Department of Mechanical Engineering, Faculty of Engineering, Universitas Negeri Malang \\ 2 Center of Nano Research and Advanced Materials, Universitas Negeri Malang \\ 3 Bachelor Program, Mechanical Engineering Department, Universitas Negeri Malang \\ *sunomo.ft@um.ac.id
}

\section{ABSTRACT}

Casting is one of method that used in forming the work piece by melting specific metal and pouring into moulding that has been prepared. This study aimed to determine the effect of the use of Bangkalan clay as binder in sand moulding against tensile strength, hardness, and defects in Al-Si casting alloy by using gravity casting method. The method used in this study was experimental method then using descriptive analysis. Descriptive analysis included explanation of the test result of tensile strength, hardness, and the type of surface defect of Al-Si casting. Based on the research result obtained the highest shear strength in wet condition obtained on sand moulding which had the highest tensile strength, that was sand moulding with composition of $12 \%$ Bangkalan clay, and $0.5 \%$ bentonite. While the highest hardness value of Al-Si casting result obtained on specimen with variation of $12 \%$ Bangkalan clay with the value of $131.9 \mathrm{HV}$. Casting defects that appeared on the surface of all casting product variations. The defects that found were fin defects, pinhole defects, sand loss defects, and surface roughness. Based on the result above, could be concluded that variation of $9 \%$ Bangkalan clay and $0.5 \%$ bentonite as binder was the best variation. Copyright (C) 2018Journal of Mechanical Engineering Science and Technology

All rights reserved

Keywords: Al-Si casting, Bangkalan clay, hardness and tensile strength.

\section{Introduction}

Metal casting process is process of working by melting the metal into liquid form at certain temperature, and then poured into a moulding which had been prepared. Casting technique is one of method that can be implement the knowledge and skills about science metal into the shape of variety of useful products [1].

There are two types of moulding that are commonly used, namely, permanent moulding and disposable moulding. Permanent moulding is cast moulding that can be used many times. Disposable moulding, generally using the sand casting method. Sand mould casting is metal casting process which is most used (over 70\%) in the manufacturing industry [2]. Sand moulding had several advantages, as follows: (1) can mould metal in high melting point, such as steel, nickel and titanium, (2) can mould the casting in small to large size, (3) the number of production from one to millions. The most affected the quality of castings were type of sand and binder [3], [4].

Sand moulding greatly affected the casting product. If the sand moulding is good, the casting result will also be good. To that end, the sand moulding had requirements that should be met, they are having formability, suitable permeability, grain size distribution that is suitable, and able to withstand the cast metal. While this type of binder has the function to bind sand moulding and also has formability in the manufacture of moulding with suitable strength and permeability [5].

In this case, Bangkalan is one of region which producing limestone in Indonesia. Mining sites of limestone is still in operation located in Bukit Jaddih. Limestone is also often referred to a rock that is generally used by the people of Indonesia as one of the building materials. Limestone included in the group of sedimentary rocks. Limestone contains of $\mathrm{CaCO}_{3}$ (calcium carbonate) [6], which can be exploited further for human resources [7]. In fact, the characteristic of the powder is known similar to the binding material like clay. 


\section{Methodology}

This study was type of pre-experimental design called the one-shot case study, in which a group of subjects were given a treatment then observed. This study used three independent variables and three dependent variables. Based on the above research methods, this study used three different types of composition of sand moulding, they were:

- $88.5 \%$ silica sand, $6 \%$ Bangkalan clay, $0.5 \%$ bentonite and $5 \%$ water.

- $85.5 \%$ silica sand, $9 \%$ Bangkalan clay, $0.5 \%$ bentonite and $5 \%$ water.

- $82.5 \%$ silica sand, $12 \%$ Bangkalan clay, $0.5 \%$ bentonite, and $5 \%$ water.

\section{Results and discussion}

\section{A. Elemental Composition Analysis}

Prior to friction welding, the composition of materials subjected to friction welding was determined using X-Ray Fluorescence (XRF) show ini Table 1.

\section{B. Microstructure}

Figure 1 showed the microstructure of Al-Si casting with percentage variation of $6 \%, 9 \%$, and $12 \%$ Bangkalan clay with the addition of $0.5 \%$ bentonite on each variation.

Table 1. The Result of XRF

\begin{tabular}{lll}
\hline No. & Compound & Concentration $(\%)$ \\
\hline 1 & $\mathrm{Mg}$ & 6.0 \\
\hline 2 & $\mathrm{Ca}$ & 92.81 \\
\hline 3 & $\mathrm{Fe}$ & $0: 24$ \\
\hline 4 & $\mathrm{Cu}$ & 0070 \\
\hline 5 & $\mathrm{Sr}$ & $0: 27$ \\
\hline 6 & $\mathrm{Yb}$ & $0: 56$ \\
\hline
\end{tabular}

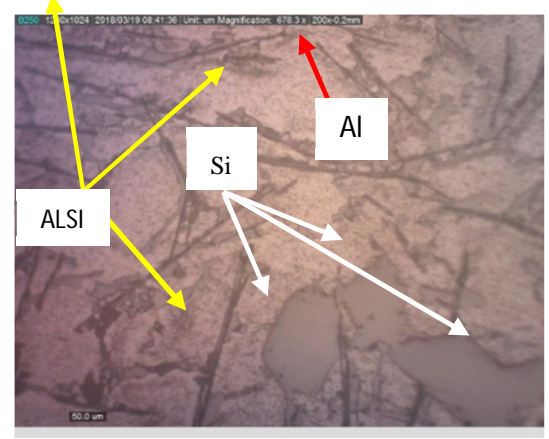

(a)

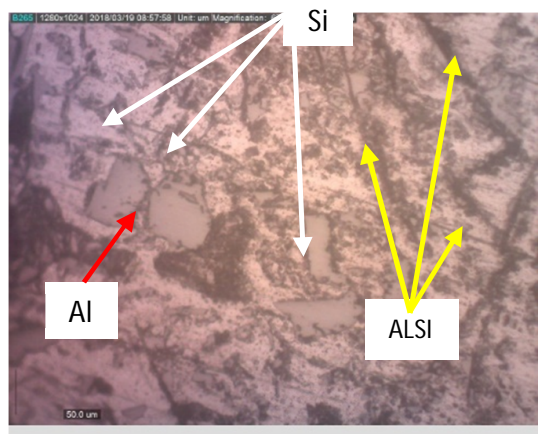

(b)

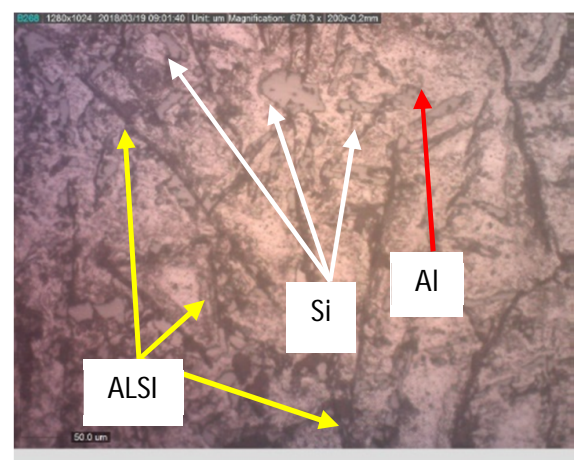

(c)

Fig. 1. Microstructure of Al-Si casting with variation of (a) 6\% Bangkalan clay, (b) 9\% Bangkalan clay, (c) $12 \%$ Bangkalan clay 
Table 2. Analysis result of macro photos

\begin{tabular}{|c|c|c|c|c|}
\hline No. & Specimens & Photos & Total Pinhole & Total Open Grain Structure \\
\hline 1 & $6 \% \mathrm{BC}+0.5 \%$ Bentonite & & $\begin{array}{c}\text { Block 1: } 33 \\
\text { Block 2: } 27 \\
\text { Block 3: } 31 \\
\text { Block 4: } 26 \\
\text { Block 5: } 32 \\
\text { Total: } 149\end{array}$ & $\begin{array}{c}\text { Block 1: } 18 \\
\text { Block 2: } 22 \\
\text { Block 3: } 20 \\
\text { Block 4: } 17 \\
\text { Block 5: } 15 \\
\text { Total: } 92\end{array}$ \\
\hline 2 & $9 \% \mathrm{BC}+0.5 \%$ Bentonite & & $\begin{array}{c}\text { Block 1: } 27 \\
\text { Block 2: } 21 \\
\text { Block 3: } 21 \\
\text { Block 4: } 28 \\
\text { Block 5: } 18 \\
\text { Total: } 115\end{array}$ & $\begin{array}{c}\text { Block 1:5 } \\
\text { Block 2:9 } \\
\text { Block 3: } 14 \\
\text { Block 4: } 7 \\
\text { Block 5: } 9 \\
\text { Total: } 44\end{array}$ \\
\hline 3 & $12 \% \mathrm{BC}+0.5 \%$ Bentonite & & $\begin{array}{c}\text { Block 1: } 10 \\
\text { Block 2: } 21 \\
\text { Block 3: } 12 \\
\text { Block 4: } 12 \\
\text { Block 5: } 21 \\
\text { Total: } 76\end{array}$ & $\begin{array}{c}\text { Block 1: } 23 \\
\text { Block 2: } 13 \\
\text { Block 3: } 15 \\
\text { Block 4: } 13 \\
\text { Block 5: } 16 \\
\text { Total: } 80\end{array}$ \\
\hline
\end{tabular}

\section{Macrostructure}

Macrostructure photo testing conducted to observe the fracture and casting defect in the surface of the specimen. The purpose of this test to analysis the properties of Al-Si casting alloy with variation of Bangkalan clay as binder in percentage of $6 \%, 9 \%$, and $12 \%$ with the addition of $0.5 \%$ bentonite on each variation. The surface analysis results of these castings result was used to obtained the kind of casting defects that occurred and their causes. This test was conducted by using camera DSLR Canon EOS 600D

1) Macro photograph in the surface of Al-Si casting with variation of Bangkalan clay

According to Table 2, the pinhole defect mostly found at specimen of Al-Si casting alloys with variations in clay binder of $6 \%$ Bangkalan clay, ie, 149 defects. While the pinhole defect at least found at the specimen of Al-Si casting alloys with variation of 12\% Bangkalan clay, ie. 76 defects. While the specimen of Al-Si casting alloy with variation of $9 \%$ Bangkalan clay had 115 pinhole defects. Table 2 also showed the open grain structure defect. Open grain structure defects mostly found at the specimen of Al-Si casting alloy with variation of 6\% Bangkalan clay, ie 92 defects. While the open grain structure defects fewest found at specimen of Al-Si casting alloys with varietion of $9 \%$ Bangkalan clay, ie. 44 defect. While the open grain structure defects on specimen $\mathrm{Al}-\mathrm{Si}$ with the variation of $6 \%$ Bangkalan clay had 80 defects.

Figure 2(a) showed the Al-Si material with percentage variation of $6 \%$ Bangkalan clay and $0.5 \%$ bentonite as binder on sand moulding, this specimen had brittle fracture. This proved by the high light-reflecting fracture and uneven fracture surface, while the metal grain looked fine. Figure 2(b) showed the Al-Si material with percentage variation of $9 \%$ Bangkalan clay $\%$ and $0.5 \%$ bentonite as binder on sand moulding, this specimen was more brittle compared to specimen in Figure 2(a). This proved by the high light-reflecting fracture and fracture surface had flatter shape than previous variations and also had fine grains. While Figure 2(c) showed the Al-Si material with percentage variation of $12 \%$ Bangkalan clay and $0.5 \%$ bentonite as binder in sand moulding, this specimen had brittle fracture, but the fracture was not as flat as the previous specimen. It was proved by the high light-reflecting fracture and fracture surface shape flatter than the previous variation and metal grains also looked fine as the previous variation. 
2) Macro photograph in the surface of Al-Si casting with variation of Bangkalan clay
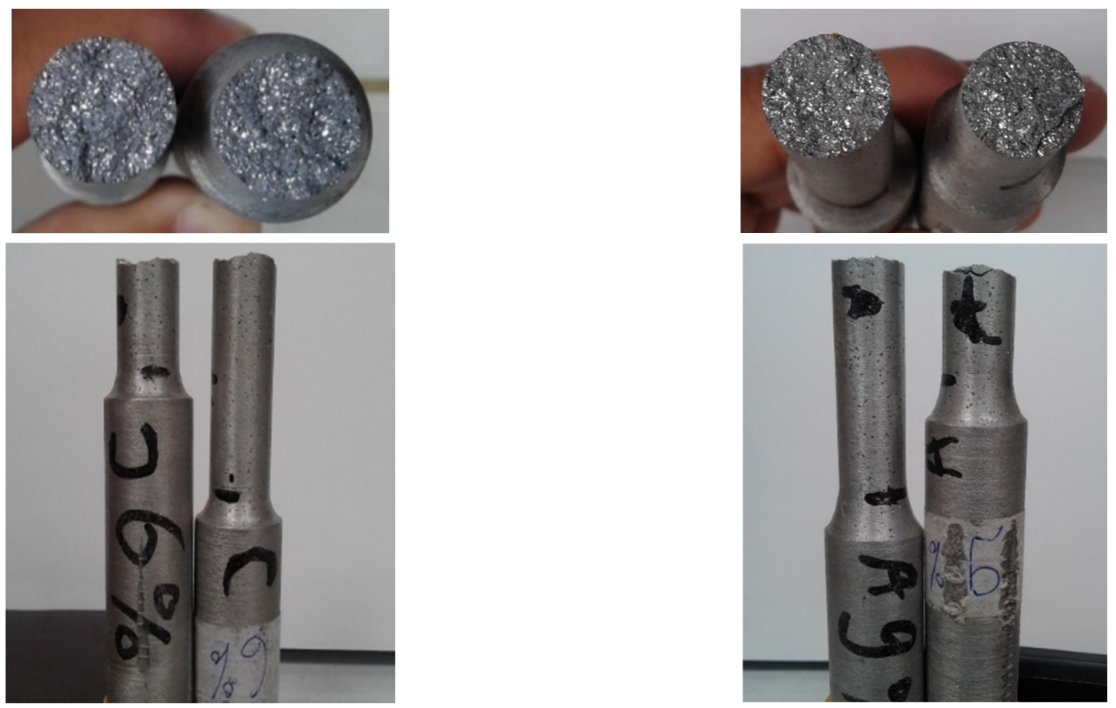

(a)

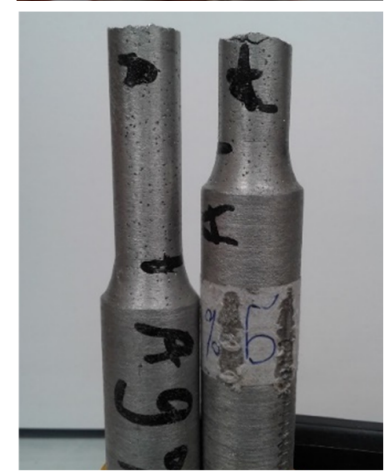

(b)
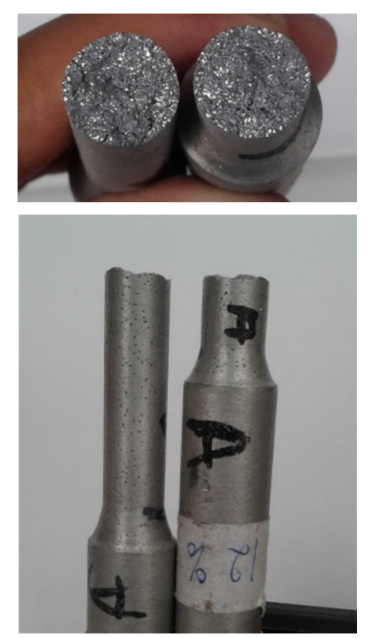

(c)

Fig. 2.Macrostructure of Al-Si casting with variation of (a) 6\% Bangkalan clay, (b) 9\% Bangkalan clay, (c) $12 \%$ Bangkalan clay

\section{Tensile Testing}

Tensile test was conducted to determine the mechanical properties of Al-Si casting alloy as test material in this study. The result of tensile test showed at the Table 3.

Table 3. The tensile test result of Al-Si with variation of $6 \%$ Bangkalan clay and $0.5 \%$ bentonite

\begin{tabular}{ccccc}
\hline \multirow{2}{*}{ No. } & \multicolumn{3}{c}{ Data Test } & Desc. \\
\cline { 2 - 5 } & $\begin{array}{c}\text { Strain } \\
(\boldsymbol{\%})\end{array}$ & Tensile strength $\left(\mathbf{k g} / \mathbf{m m}^{\mathbf{2}}\right)$ & Yield strength $\left(\mathbf{k g} / \mathbf{m m}^{\mathbf{2}}\right)$ & \\
\hline 1 & 2.326 & 11.505 & 11.444 & Not Valid \\
\hline 2 & 0.519 & 10.240 & 10.403 & Valid \\
\hline 3 & 0.759 & 11.444 & 11.262 & Valid \\
\hline Average & 0.639 & 10.842 & 10.832 & \\
\hline
\end{tabular}


Table 4. The tensile test result of Al-Si with variation of $9 \%$ Bangkalan clay and $0.5 \%$ bentonite

\begin{tabular}{ccccc}
\hline No. & \multicolumn{3}{c}{ Data Test } & \multicolumn{2}{c}{ Desc. } \\
\cline { 2 - 5 } & $\begin{array}{c}\text { Strain } \\
(\boldsymbol{\%})\end{array}$ & Tensile strength $\left(\mathbf{k g} / \mathbf{m m}^{\mathbf{2}}\right)$ & Yield strength $\left(\mathbf{k g} / \mathbf{m m}^{2}\right)$ & \\
\hline 1 & 1.339 & 10.622 & 10.908 & Valid \\
\hline 2 & 0.602 & 11.147 & 10.908 & Valid \\
\hline 3 & 0.360 & 10.761 & 10.702 & Valid \\
\hline Average & 0.767 & 10.843 & 10.839 & \\
\hline
\end{tabular}

Table 5. The tensile test result of Al-Si with variation of $12 \%$ Bangkalan clay and $0.5 \%$ bentonite

\begin{tabular}{ccccc}
\hline No. & \multicolumn{3}{c}{ Data Test } & Desc. \\
\cline { 2 - 5 } & $\begin{array}{c}\text { Strain } \\
(\boldsymbol{\%})\end{array}$ & Tensile strength $\left(\mathbf{k g} / \mathbf{m m}^{\mathbf{2}}\right)$ & Yield strength $\left(\mathbf{k g} / \mathbf{m m}^{\mathbf{2}}\right)$ & \\
\hline 1 & 0.792 & 10.996 & 11.341 & Valid \\
\hline 2 & 0.919 & 11.381 & 11.290 & Valid \\
\hline 3 & 0.982 & 11.527 & 11.402 & Not Valid \\
\hline Average & 0.898 & 11.188 & 11.315 & \\
\hline
\end{tabular}

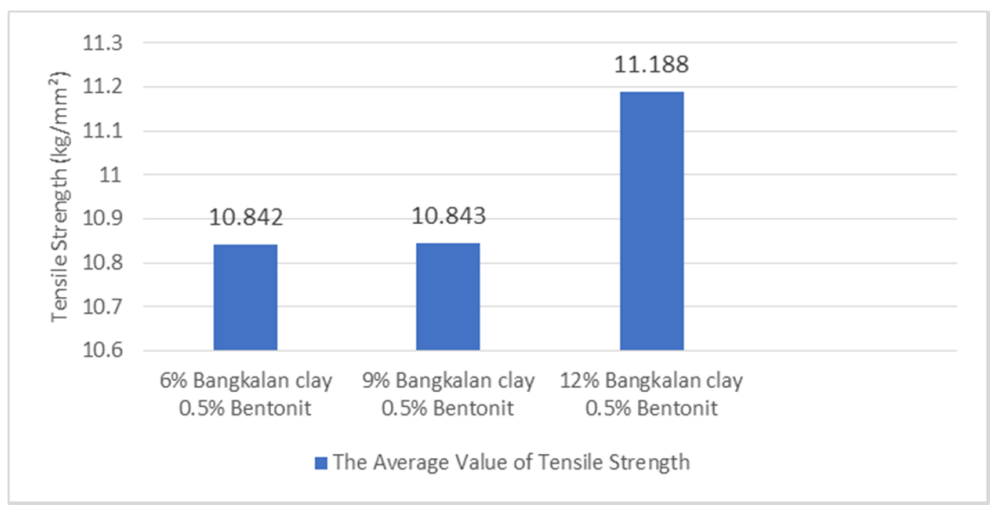

Fig. 3. The Average Value of Tensile Strength Al-Si Casting

Table 6. The hardness test result of Al-Si with variation of $6 \%$ Bangkalan clay and $0.5 \%$ bentonite

\begin{tabular}{cccccc}
\multirow{2}{*}{ No. Specimen } & \multicolumn{3}{l}{ Hardness Value (HV) at Three Points } & Average \\
\cline { 3 - 5 } & & \multicolumn{1}{c}{} & $\boldsymbol{2}$ & $\mathbf{3}$ & \\
\cline { 3 - 5 } & 1 & 108.6 & 115.7 & 118.3 & 114.2 \\
\hline
\end{tabular}

The description in Table 3, 4, 5 showed that all of specimens were valid due to the fracture results passed the gauge length. The diagram of tensile test result showed at Figure 3.

\section{E. Microhardness Testing}

Microvickers hardness testing conducted to understand the hardness value of casting product using Microvickers Hardness Tester. The scale of hardness used was HV (Vickers Hardness) with pyramidal diamond indenter penetration force of 200 grams and dwell for 10 seconds. Hardness test conducted at three different points on the surface of each specimen. The result of hardness testing on $\mathrm{Al}-\mathrm{Si}$ casting that resulted on casting process by using percentage variation of $6 \%, 9 \%, 12 \%$ Bangkalan clay and $0.5 \%$ bentonite as binder in sand moulding was showed in the several tables as follow. 
Table 7. The hardness test result of Al-Si with variation of $9 \%$ Bangkalan clay and $0.5 \%$ bentonite

No. Specimen

Hardness Value (HV) at Three Points Average

\begin{tabular}{cccccc}
\cline { 3 - 5 } & & $\mathbf{1}$ & $\mathbf{2}$ & $\mathbf{3}$ & \\
\cline { 1 - 5 } 1 & 1 & 117.7 & 108.4 & 129.3 & 118.47 \\
\hline
\end{tabular}

Table 8 . The hardness test result of Al-Si with variation of $12 \%$ Bangkalan clay and $0.5 \%$ bentonite

\begin{tabular}{cccccc}
\multirow{2}{*}{ No. } & Specimen & \multicolumn{2}{c}{ Hardness Value (HV) at Three Points } & Average \\
& & \multicolumn{3}{c}{} & \\
\cline { 3 - 5 } & & $\mathbf{1}$ & $\mathbf{2}$ & $\mathbf{3}$ & \\
\hline 1 & 1 & 138.5 & 127.4 & 129.8 & 131.9 \\
\hline
\end{tabular}

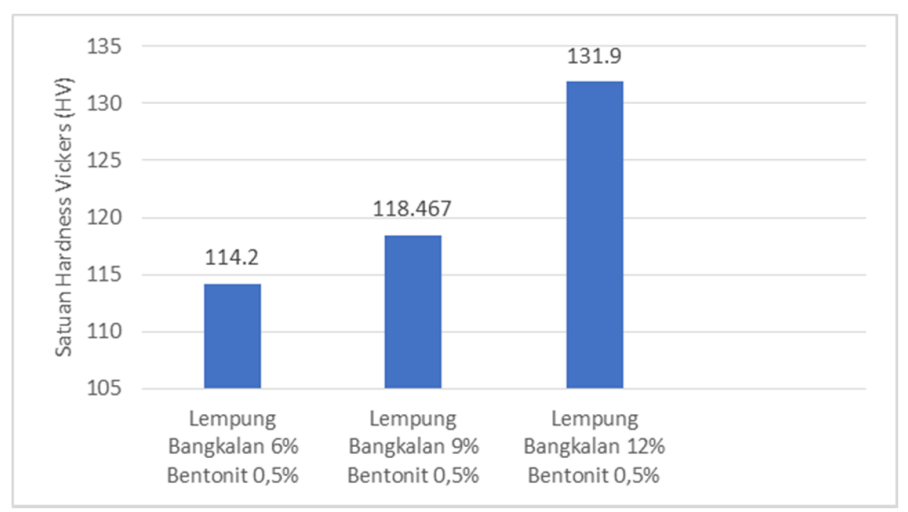

Fig. 4. The Average Value of Hardness Strength Al-Si Casting.

Table 6 showed the average hardness value on specimen of Al-Si alloy with variation of $6 \%$ Bangkalan clay and $0.5 \%$ bentonite as binder in sand moulding had the value of $114.2 \mathrm{HV}$

Table 7 showed the average hardness value on specimen of Al-Si alloy with variation of $9 \%$ Bangkalan clay and $0.5 \%$ bentonite as binder in sand moulding had the value of $118.47 \mathrm{HV}$

Table 8 showed the average hardness value on specimen of Al-Si alloy with variation of $12 \%$ Bangkalan clay and $0.5 \%$ bentonite as binder in sand moulding had the value of $131.9 \mathrm{HV}$. The diagram of hardness test showed at Figure 4.

\section{Conclusion}

According to the result could be determined that the use of $12 \%$ Bangkalan clay was the recommendation variation to get the best result in manufacturing sand molding for Al-Si casting.

\section{References}

[1] H. Sujana, “Teknik Pengecoran Logam,” J. Chem. Inf. Model., vol. 53, no. 9, hal. 1689-1699, 2013.

[2] S. Shahria, M. Tariquzzaman, M. Habibur Rahman, M. Al-Amin, dan M. Abdur Rahman, "Optimization of molding sand composition for quality improvement of iron castings," Appl. Clay Sci., vol. 67-68, no. May, hal. 26-31, 2012.

[3] M. A. S. I Made Astika, DNK Putra Negara, "Pengaruh Jenis Pasir Cetak dengan Zat Pengikat Bentonit Terhadap Sifat Permeabilitas dan Kekuatan Tekan Basah Cetakan Pasir ( Sand Casting )," J. Ilm. Tek. Mesin Cakram, vol. 4, no. 2, hal. 132-138, 2010.

[4] Anon, "Sand/binders/sand preparation/mold \&amp; coremaking," Foundry Manag. Technol., vol. 124, no. $1,1996$. 
[5] W. A. Ayoola, S. O. Adeosun, O. S. Sanni, dan A. Oyetunji, "Effect of casting mould on mechanical properties of 6063 aluminum alloy," J. Eng. Sci. Technol., vol. 7, no. 1, hal. 89-96, 2012.

[6] F. S. Murakami, P. O. Rodrigues, C. Maria, T. De Campos, M. Antônio, dan S. Silva, "Physicochemical study of CaCO 3 from egg shells," vol. 27, no. 3, hal. 658-662, 2007.

[7] J. J. Darren, D. Gunaran, H. Hendy, dan E. K. Budirahardjo, "Pengaruh Penambahan Gabungan Batu Kapur the Effect dan Batu Kapur Padam pada Campuran Beton K-300,” hal. 141-148. 